Biota Vol. IX (3): 129-135, Oktober 2004 ISSN 0853-8670

\title{
Karakterisasi $\alpha$-Amilase Bacillus firmus KH.9.4 Alkalotoleran dari Limbah Cair Tapioka
}

Characterization of $\alpha$-Amylase Producing Bacillus firmus KH.9.4 Alkalotolerant Isolated from Tapioka Liquid Waste

\author{
Nisa Rachmania ${ }^{1 *}$, Ruma Iswati ${ }^{1}$, Tedja $\operatorname{Imas}^{1}$ \\ ${ }^{1}$ Departemen Biologi, FMIPA, Institut Pertanian Bogor, Jalan Raya Pajajaran, Bogor 16144, \\ Tel./Fax.+62-251-345011, e-mail: riknisa@telkom.net. *penulis untuk korespondensi
}

\begin{abstract}
Alkalotolerant bacteria identified as Bacillus firmus KH.9.4 was isolated from tapioca liquid waste from Kedung Halang, Bogor. The isolate showed optimum $\alpha$-amylase activity after 15 hours of cultivation on liquid media. Optimum enzyme activity occurred at $\mathrm{pH} 6.0$ and temperature $80^{\circ} \mathrm{C}$. Upon heat treatment at $\mathrm{pH} 6.0$ and $80^{\circ} \mathrm{C}$ the enzyme was still $100 \%$ active after 6 hours incubation without substrate. The enzyme activity was enhanced by supplement $10 \mathrm{mM} \mathrm{MgSO}_{4} .7 \mathrm{H}_{2} \mathrm{O}$. The presence of 1,5 , and 10 $\mathrm{mM}$ ethylenediaminetetraacetic acid demonstrated the inhibitory effect to this enzyme. Zymogram analysis revealed one translucent zone corresponding to soluble starch activities after 60 minutes of incubation at $40^{\circ} \mathrm{C}$ in the $0.05 \mathrm{M}$ phoshate buffer pH 7.0. Whereas SDS-PAGE analysis showed that there are 5 bands of proteins.
\end{abstract}

Key words: $\alpha$-amylase activity, Bacillus firmus, tapioka liquid waste

Diterima: 30 Oktober 2003, disetujui: 31 Maret 2004

\section{Pendahuluan}

Indonesia merupakan negara penghasil tapioka terbesar ke-2 dunia setelah Thailand (Veltlamp dan Bruijn, 1996). Di beberapa daerah Indonesia dijumpai industri pengolahan pati tapioka baik industri besar maupun rumah tangga. Pengolahan ubi kayu menjadi pati tapioka menghasilkan limbah berkadar pati hingga 50\% (Nishise et al., 1988) yang dapat dimanfaatkan oleh mikroorganisme pengurai pati.

$\alpha$-Amilase (1,4- $\alpha$-D-glucan glucanohydrolase, EC 3.2.1.1) merupakan salah satu enzim amilolitik yang mempunyai kemampuan untuk menghidrolisis pati pada ikatan $\alpha-1,4$ glukosidik menjadi monosakarida dan disakarida (Fogarty, 1983). Dalam industri pangan, $\alpha$-amilase berperan dalam mempercepat proses hidrolisis dengan menurunkan viskositas pati (Nigam dan Singh,
1995). $\alpha$-amilase yang biasa digunakan berasal dari bakteri Bacillus licheniformis dan $B$. subtilis yang mempunyai aktivitas optimum pada pH 6,0-7,0 (McTigue et al.,1995). Kroll (1990) mengatakan bahwa beberapa amilase telah diisolasi dari bakteri alkalofilik dan mampu menghidrolisis 30-70\% pati menjadi glukosa, maltosa, dan oligosakarida.

Salah satu bakteri amilolitik koleksi biakan laboratorium Mikrobiologi, Departemen Biologi, FMIPA, IPB adalah B. firmus KH.9.4 (Mubarik et al., 2001). Isolat ini diisolasi dari limbah cair pengolahan pati tapioka di Kedung Halang (KH), Bogor dan diberikan kode 9.4. B. firmus KH.9.4 mampu tumbuh serta menghasilkan zona amilolitik pada $\mathrm{pH}$ 6,0-10,0 pada media padat yang mengandung pati tapioka $2 \%$. Informasi dari Claus dan Berkely (1986) menyebutkan bahwa B. firmus, selain bersifat amilolitik juga proteolitik karena dapat menghidrolisis gelatin dan kasein. Penelitian 
ini bertujuan untuk melakukan karakterisasi $\alpha-$ amilase yang berasal dari bakteri $B$. firmus KH.9.4.

\section{Metode Penelitian}

\section{Pertumbuhan Bakteri dan Produksi $\alpha$-Amilase Bacillus firmus KH.9.4}

Isolat bakteri ditumbuhkan di dalam media Lin et al., termodifikasi (1998) yang mengandung $10 \mathrm{~g}$ ekstrak khamir, $10 \mathrm{~g}$ pati tapioka, $0,5 \mathrm{~g} \quad \mathrm{MgSO}_{4} 7 \mathrm{H}_{2} 0$, dan $0,13 \mathrm{~g}$ $\mathrm{K}_{2} \mathrm{HPO}_{4}$ untuk 1 liter media, $\mathrm{pH}$ 9,0. Pengaturan $\mathrm{pH}$ media menggunakan larutan $\mathrm{NaHCO}_{3} \quad 10 \%$ steril. Sebanyak 2\% inokulum cair $\left( \pm 10^{8} \mathrm{sel} / \mathrm{ml}\right)$ umur 6 jam diinokulasikan ke dalam $100 \mathrm{ml}$ media produksi. Biakan diinkubasi dalam penggojong dengan kecepatan $160 \mathrm{rpm}$ suhu $30^{\circ} \mathrm{C}$. Pertumbuhan bakteri diukur berdasarkan perubahan kekeruhan media produksi setiap 3 jam pada panjang gelombang $(\lambda) 620 \mathrm{~nm}$. Setiap selang waktu 3 jam bersamaan dengan pengukuran turbiditas pertumbuhan, kultur bakteri disentrifugasi pada kecepatan $5000 \mathrm{~g}$ dengan menggunakan sentrifuse dingin (suhu $4^{\circ} \mathrm{C}$ ) selama 15 menit. Supernatan yang mengandung amilase ekstrak kasar diambil dan digunakan untuk uji enzim.

\section{Produksi dan Pengukuran Aktivitas $\alpha$-Amilase}

Enzim dipanen pada saat waktu pertumbuhan optimum berdasarkan kurva pertumbuhan yang telah diperoleh. Produksi enzim pada media cair yang berkomposisi sama dengan metode batch menggunakan Erlenmeyer. Media produksi diinkubasi selama 15 jam pada pH 9,0 dan suhu $30^{\circ} \mathrm{C}$. Aktivitas $\alpha$-amilase diukur dengan metode Bernfeld (1955), yaitu sebanyak $1 \mathrm{ml}$ filtrat enzim ditambahkan ke dalam $1 \mathrm{ml}$ larutan $1 \%$ pati terlarut. Campuran diinkubasi selama 15 menit suhu $30^{\circ} \mathrm{C}$, dilanjutkan dengan penambahan 2 $\mathrm{ml}$ asam dinitrosalisilat (DNS). Campuran diinkubasi selama 5 menit pada $100^{\circ} \mathrm{C}$, dan setelah dingin absorbansi diukur dengan spektofotometer pada $\lambda 550 \mathrm{~nm}$. Satu unit aktivitas enzim didefinisikan sebagai jumlah enzim yang diperlukan untuk melepaskan 1 $\mu$ mol gula pereduksi per menit atau setara dengan $1 \mu \mathrm{mol}$ maltosa/menit. Kurva standar maltosa diukur pada kisaran konsentrasi 0-400 ppm dengan selang $50 \mathrm{ppm}$. Kadar protein ditentukan dengan metode Bradford (1976). Sebanyak $60 \mu \mathrm{l}$ filtrat enzim direaksikan dengan $3 \mathrm{ml}$ preaksi Bradford. Absorbansi dibaca pada $\lambda 595 \mathrm{~nm}$. Bovine serum albumin (BSA) dengan kisaran konsentrasi 0-2,0 mg/ml digunakan sebagai standar.

\section{Karakterisasi Aktivitas $\alpha$-Amilase}

Aktivitas $\alpha$-amilase diukur pada pH 5 10 (dengan selang satu unit) pada suhu $30^{\circ} \mathrm{C}$. Untuk menentukan $\mathrm{pH}$ optimum, yaitu $\mathrm{pH}$ yang memiliki aktivitas $\alpha$-amilase tertinggi, substrat pati dilarutkan dalam bufer asam sitrat $0,05 \mathrm{M}$ (pH 5,0 dan 6,0), bufer Tris $\mathrm{HCl} \mathrm{0,05}$ $\mathrm{M}(\mathrm{pH} 7,0$ dan 8,0), dan bufer glisin- $\mathrm{NaOH}$ $0,05 \mathrm{M}$ (pH 9,0 dan 10,0). Penentuan suhu optimum aktivitas $\alpha$-amilase dilakukan dengan cara mengukur aktivitas enzim pada kisaran suhu $20^{\circ} \mathrm{C}-80^{\circ} \mathrm{C}$ dengan selang $10^{\circ} \mathrm{C}$. Kestabilan panas enzim diukur dengan cara menginkubasi enzim pada $\mathrm{pH}$ dan suhu optimumnya selama 6 jam inkubasi. Kemudian setiap 1 jam sekali dilakukan pengukuran aktivitas enzim.

Pengaruh penambahan kation terhadap aktivitas $\alpha$-amilase diujikan dengan menggunakan senyawa kation divalen yang digunakan ialah: $\mathrm{CaCl}_{2} 2 \mathrm{H}_{2} \mathrm{O}, \mathrm{CoCl}_{2} 6 \mathrm{H}_{2} \mathrm{O}$, $\mathrm{CuSO}_{4}, \quad \mathrm{FeSO}_{4}, \quad \mathrm{MgSO}_{4} 7 \mathrm{H}_{2} \mathrm{O}$, dan $\mathrm{ZnCl}_{2}$ hingga mencapai konsentrasi akhir $10 \mathrm{mM}$. Selain itu diuji pengaruh penambahan senyawa pengkelat logam etilendiamintetraasetat (EDTA) dengan konsentrasi akhir $10 \mathrm{mM}$. Konsentrasi akhir adalah konsentrasi senyawa kation divalen atau EDTA dalam campuran filtrat enzim dan bufer. Aktivitas $\alpha$-amilase diukur pada $\mathrm{pH}$ dan suhu optimum.

Elektroforesis menggunakan gel poliakrilamida-sodium dodesil sulfat (SDSPAGE). Berat molekul protein diukur dengan standar berat molekul tinggi (Pharmacia). Elektroforesis protein menggunakan gel pemisah $8 \%$ poliakrilamida dan gel penahan (stacking gel) 4\% poliakrilamida (Bollag and Edelstein, 1991). Gel pemisah (separating gel) 
pada zimogram mengandung $1 \%$ pati terlarut. Sebelum dimasukkan ke dalam sumur, sampel protein yang telah ditambah bufer (1:1) diinkubasi dalam air mendidih selama 1 menit, kecuali untuk zimogram tidak dipanaskan Volume sampel yang dimasukkan ke dalam sumur berkisar 10-20 $\mu$ l. Proses elektroforesis berlangsung selama 1 jam dengan kondisi 100 $\mathrm{mv}$ dan $50 \mathrm{~mA}$. Larutan pewarna gel mengandung perak nitrat $0,1 \%$. Setelah direndam 30 menit dalam larutan pewarna, gel dicuci dengan aquades dan developer, reaksi dihentikan dengan larutan asam sitrat 2,3 M. Gel untuk zimogram diberi perlakuan setelah elektroforesis direndam dalam Triton X-100 $2,5 \%$ selama satu jam. Kemudian cairan dibuang dan diganti dengan bufer fosfat 0,05 $\mathrm{M} \mathrm{pH} \mathrm{7,0} \mathrm{selama} 1$ jam sambil digoyang konstan pada suhu $40^{\circ} \mathrm{C}$. Larutan tersebut diganti dengan larutan pewarna KI $0,01 \mathrm{~N}$. Molekul protein yang bersifat amilolitik akan tampak berwarna bening, sedangkan pati yang tidak terhidrolisis berwarna biru.

\section{Hasil dan Pembahasan}

\section{Pertumbuhan Bakteri dan Produksi $\alpha$ - Amilase Bacillus firmus KH.9.4.}

Aktivitas $\alpha$-amilase $B$. firmus KH.9.4 mencapai nilai maksimum pada jam ke-15 pertumbuhan dengan nilai aktivitas sebesar $0,84 \mathrm{U} / \mathrm{ml}$, kadar proteinnya sebesar 0,80 $\mathrm{mg} / \mathrm{ml}$, dan aktivitas spesifik $1,05 \mathrm{U} / \mathrm{mg}$ (Gambar 1). Hingga 9 jam pertumbuhan, turbiditas sel meningkat cepat, dan setelahnya relatif statis hingga jam ke-24. Dengan demikian pada saat aktivitas maksimum tercapai diduga sel berada pada fase stasioner pertumbuhan. Bacillus sp. IMD 370 (McTigue et al., 1995) dan Lactobacillus cellobiosus D39 (Sen and Chakrabarty, 1984) juga menghasilkan aktivitas amilase yang maksimum pada fase stasioner.

\section{Karakterisasi $\alpha$ - Amilase Ekstraseluler}

$\alpha$-amilase $B$. firmus KH.9.4 mencapai aktivitas optimum pada pH 6,0 (Gambar 2) dan suhu $80^{\circ} \mathrm{C}$ (Gambar 3). Meskipun biakan ini ditumbuhkan pada media dengan $\mathrm{pH} 9,0$, namun ternyata memiliki $\mathrm{pH}$ optimum seperti sebagian besar $\alpha$-amilase bakteri lainnya sekitar 5-6 (Freer, 1993; Mc Tigue et al., 1995). Uji kestabilan suhu $\alpha$-amilase $B$. firmus KH.9.4 menunjukkan aktivitas yang relatif stabil selama 6 jam inkubasi pada suhu $80^{\circ} \mathrm{C}$ dan pH 6,0 (Gambar 4). Kestabilan aktivitas dari satu hingga lima jam inkubasi menunjukkan $\alpha$-amilase $B$. firmus KH.9.4 berpotensi sebagai enzim termostabil. Salah satu definisi enzim termostabil seperti yang dikemukakan Ng and Kenealy (1986) memiliki suhu aktivitas enzim optimum di atas suhu pertumbuhan isolate penghasilnya.

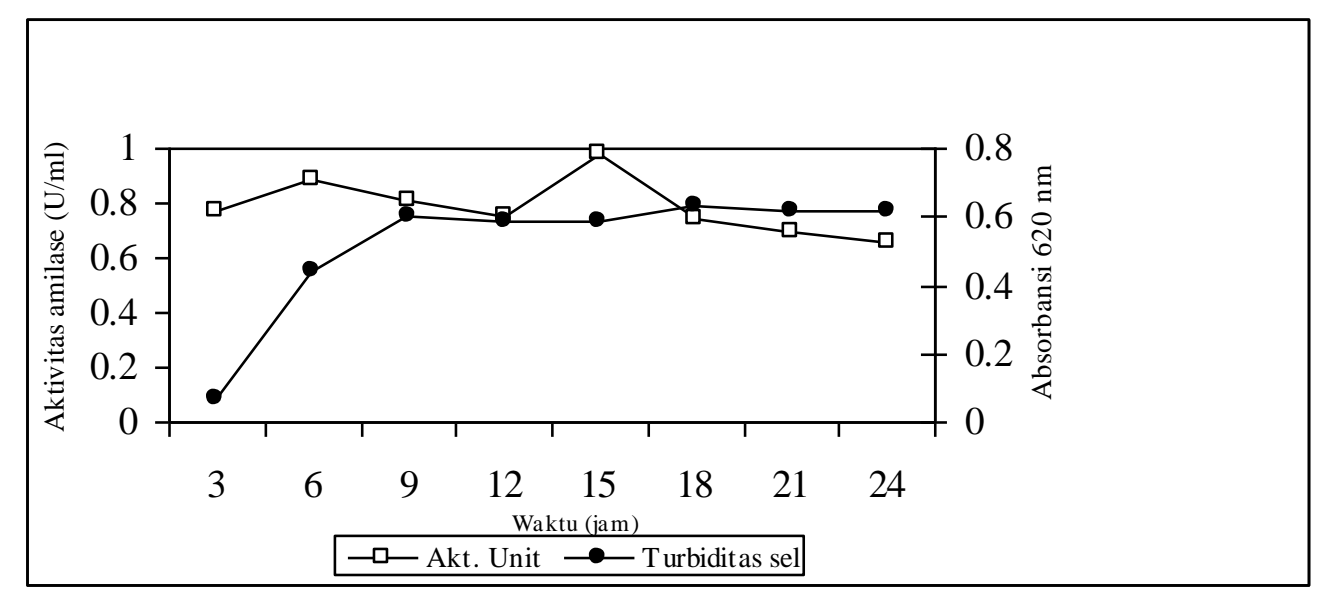

Gambar 1. Kurva pertumbuhan B. firmus KH.9.4 dan aktivitas $\alpha$-amilase. 


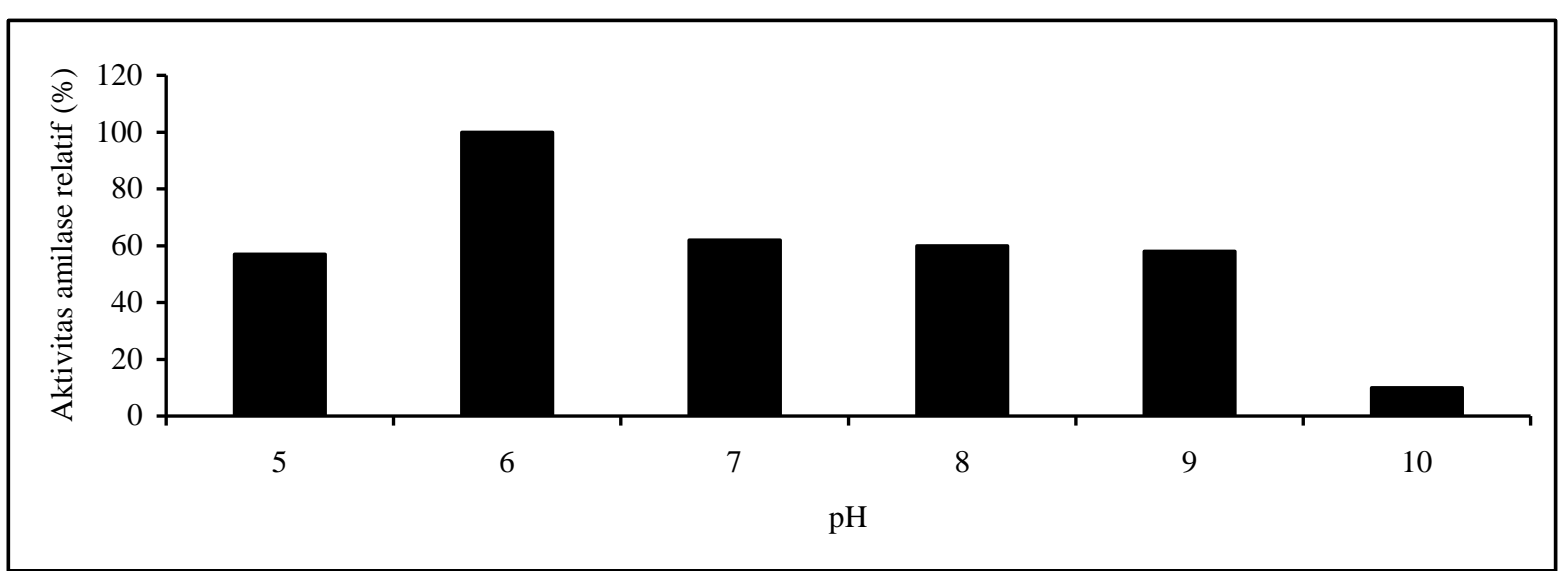

Gambar 2. Pengaruh pH terhadap aktivitas $\alpha$-amilase B. firmus KH.9.4 pada suhu $30^{\circ} \mathrm{C}$.

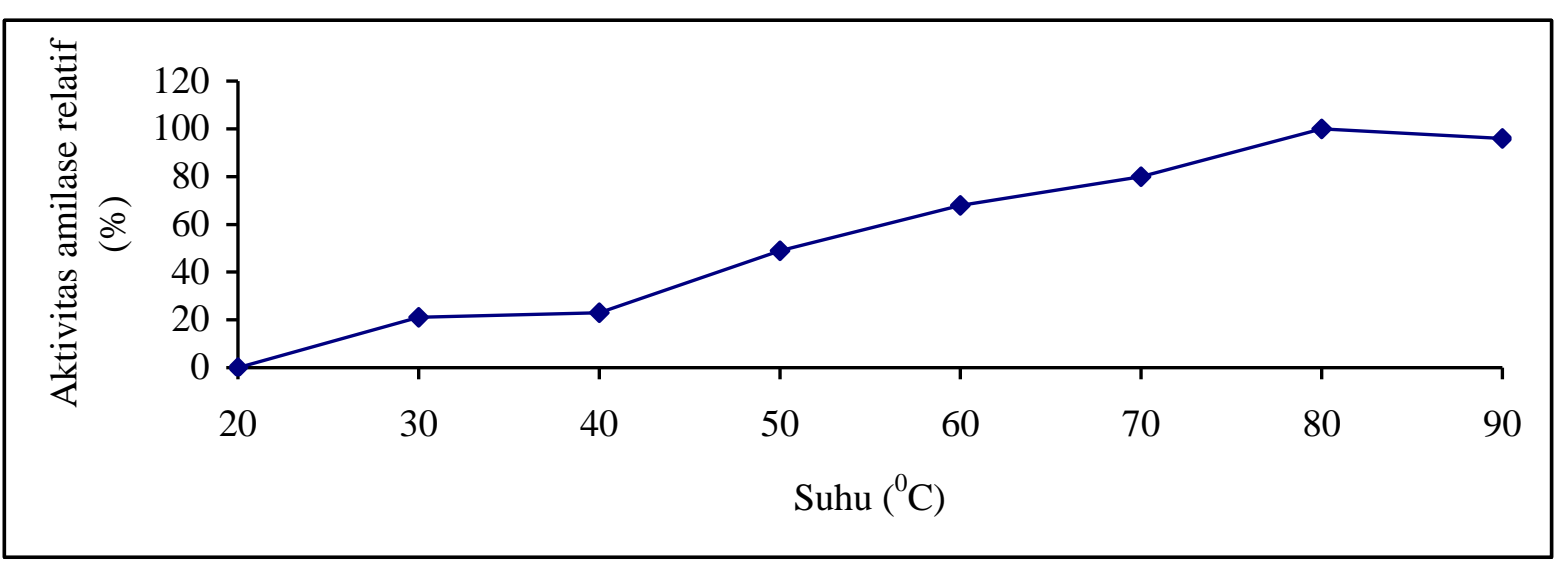

Gambar 3. Pengaruh suhu terhadap aktivitas $\alpha$-amilase B. firmus KH.9.4 pada pH 6,0.

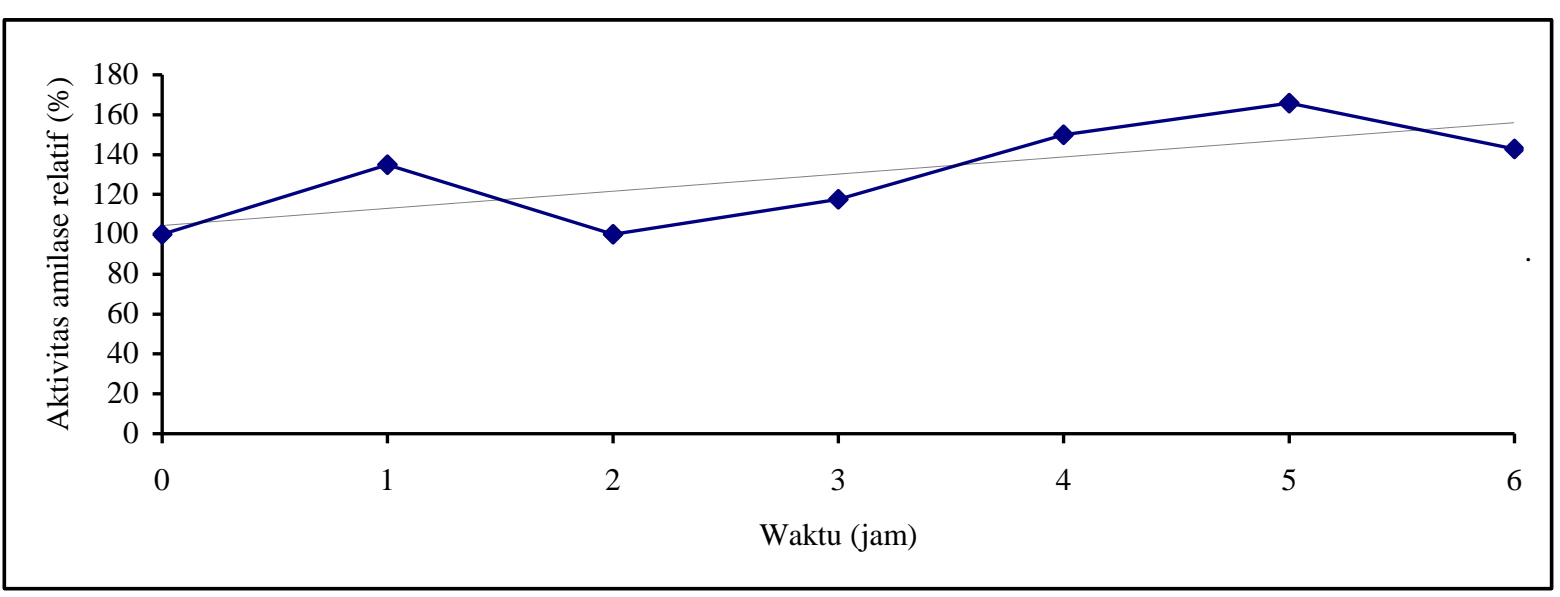

Gambar 4. Stabilitas aktivitas $\alpha$-amilase B. firmus KH.9.4 pada suhu $80^{\circ} \mathrm{C}$ pH 6,0. 
Setiap $\alpha$-amilase dari sumber yang berbeda memberikan respons yang berbeda terhadap penambahan senyawa kation divalen (Lin et al., 1998). Penambahan $10 \mathrm{mM}$ kation divalen $\mathrm{Mg}^{2+}$ meningkatkan aktivitas $\alpha$-amilase $B$. firmus KH.9.4 hingga 122,6 \% Penambahan $10 \quad \mathrm{mM} \quad \mathrm{Cu}^{2+}$ menurunkan aktivitasnya hingga tersisa 9,9\% (Gambar 5). Lin et al., (1998) menyebutkan $\mathrm{Cu}^{2+}$ merupakan salah satu kation yang menghambat kuat aktivitas $\alpha$-amilase asal mikrob di samping $\mathrm{Pb}^{2+}$ dan $\mathrm{Hg}^{2+}$ Ion kalsium mempunyai peranan penting bagi struktur enzim terutama dalam mempertahankan kestabilan enzim terhadap panas. Sebagian besar $\alpha$-amilase tetap stabil pada suhu tinggi karena kehadiran $\mathrm{Ca}^{2+}(\mathrm{Ng}$ and Kenealy, 1986). Namun penambahan ion $\mathrm{Ca}^{2+} 10 \mathrm{mM}$ menurunkan aktivitas $\alpha$-amilase $B$. firmus KH.9.4 sebesar $4.5 \%$ dibandingkan kontrol. Senyawa pengkelat EDTA dikenal sebagai penghambat metaloenzim. Penurunan aktivitas $\alpha$-amilase setelah direaksikan dengan EDTA menunjukkan bahwa enzim tersebut membutuhkan ion logam untuk aktivitasnya. Aktivitas $\alpha$-amilase $B$. firmus KH.9.4 menurun setelah direaksikan $10 \mathrm{mM}$ senyawa EDTA. Hal seperti ini ditunjukkan pula oleh $\alpha$-amilase Bacillus sp. TS-23 (Lin et al., 1998) dan Bacillus sp. IMD 370 dengan menggunakan konsentrasi EDTA $1 \mathrm{mM}$ dan $10 \mathrm{mM}$ (McTigue et al., 1995).

Hasil SDS-PAGE $\alpha$-amilase $B$. firmus KH.9.4 menunjukkan terdapat 1 pita protein yang tebal berukuran $32,1 \mathrm{kD}$ dan 4 pita protein yang tipis. Hasil zimogram dijumpai 1 pita protein yang menunjukkan aktivitas amilolitik yang terdapat di atas gel pemisah dengan berat molekul yang belum diketahui. Berdasarkan hasil ini perlu digunakan penanda berat molekul yang lebih besar dan perlu dilakukan kembali optimisasi proses zimogram untuk dapat menentukan pita protein yang memiliki aktivitas amilolitik tersebut (Gambar $6)$.

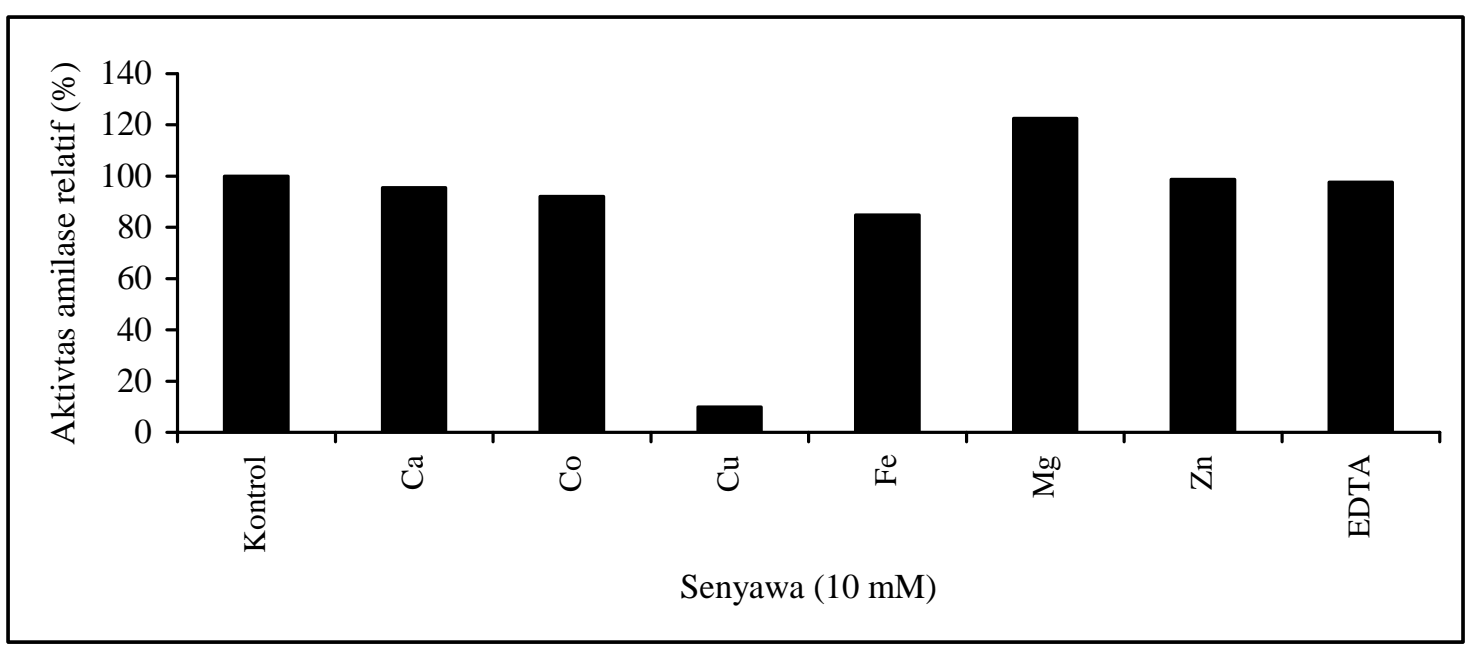

Gambar 5. Pengaruh penambahan senyawa kation dan EDTA terhadap aktivitas $\alpha$-amilase $B$. firmus KH.9.4 pada suhu $80^{\circ} \mathrm{pH}$ 6.0. 


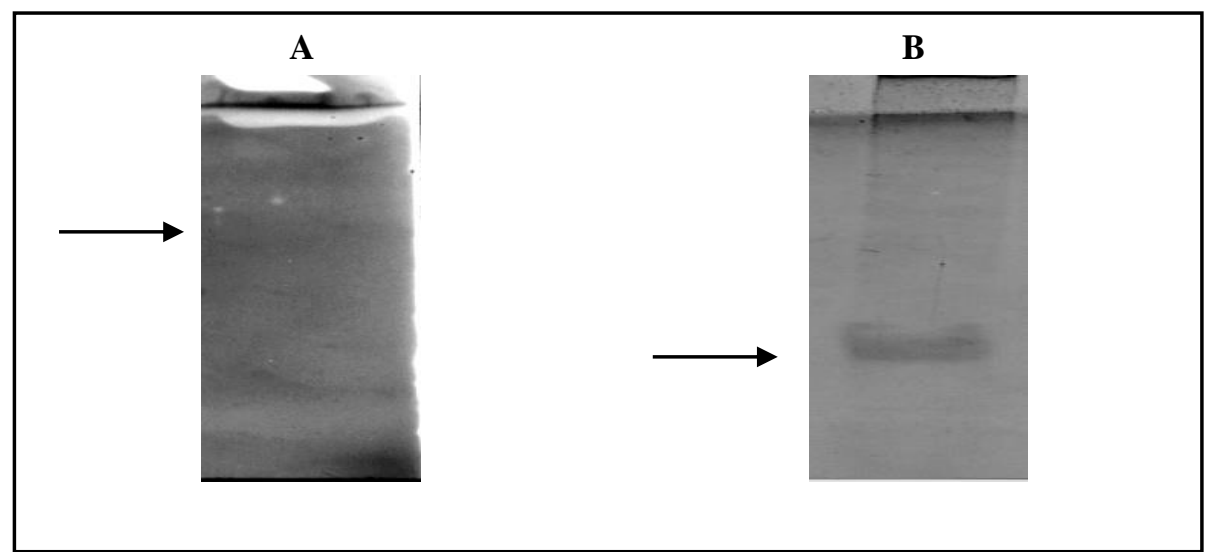

Gambar 6. (A) Hasil zimogram pita protein B. firmus KH.9.4 yang memiliki aktivitas amilolitik (bertanda panah) dan (B) Hasil SDS-PAGE pita berukuran $32,1 \mathrm{kDa}$ (bertanda panah).

\section{Kesimpulan}

Dari hasil penelitian ini isolat $B$. firmus KH.9.4 yang diisolasi dari limbah cair tapioka berpotensi sebagai penghasil enzim $\alpha$-amilase. Aktivitas $\alpha$-amilase yang dihasilkannya relatif stabil pada suhu $80^{\circ} \mathrm{C}$ di atas suhu pertumbuhan isolat penghasilnya (suhu $30^{\circ} \mathrm{C}$ ).

\section{Ucapan Terima Kasih}

Penelitian ini didanai oleh Project Grant QUE Tahun 1999-2000. Departemen Biologi, FMIPA, Institut Pertanian Bogor dan Penelitian Dasar Tahun 2003, Ditjen Dikti, Depdiknas.

\section{Daftar Pustaka}

Bernfeld, P. 1955. Amylases $\alpha$ - and $\beta$-. In: Colowick, S.P., N.O. Kaplan (Eds). Methods in EnzymologyI. pp. 149-150. Academic Pr. New York.

Bradford, M.M. 1976. A rapid and sensitive method for the quantition of microorganisms quantities of protein in utilizing the principle dye-binding. Anal. Biochem. 17:570-573.

Bollag, D.M. and Edelstein, S.J. 1991. Protein Methods. Wiley-Liss. New York.
Claus, D. and Berkely, W. 1986. Bacillus. In: Buttler, J.P. (Ed). Bergey's Manual of Systematic Bacteriology. Vol 2. pp. 1105-1113. Waverley Press. New York.

Fogarty, W.M. 1983. Microbial amylases. In: Fogarty, W.M. (Ed). Microbial Enzymes and Biotechnology. pp. 1-92. Applied Science. London.

Freer, S.N 1993. Purification and characterization of the extracellular $\alpha$-amylase from Streptococcus bovis JB1. Appl. Environ. Microbiol. 59:1398-1402.

Kroll, R.G. 1990. Alkalophiles. In: Edwards, C. (Ed). Microbiology of Extreme Environtments. pp. 5592. McGraw Pub. New York.

Lin, L-L., Chyaw, C-C and Hsu, W-H 1998. Production and properties of a raw-starch-degrading amylase from the thermophilic and alkaliphilic Bacillus sp. TS-23. Biotechnol. Appl. Biochem. 28:61-68.

McTigue, M.A., Kelly, C.T., Doyle, E.M. and Fogarty, W.M. 1995. The alkaline amylase of the alkalophilic Bacillus sp. IMD 370 Enzyme Microb. Technol. 17:570-573

Mubarik, N.R., Listyowati, S., Imas, T., Purnama, R.D., Iswati, R., Damayanti, E. and Handayani, D. 2001. Isolasi dan Karakterisasi Enzim Amilolitik 2001. Isolasi dan Karakterisasi Enzim Amilolitik
dari Mikrob Limbah Cair Tapioka. Laporan Akhir Penelitian Proyek QUE Jurusan Biologi Tahun 1999-2000. IPB. FMIPA. Jurusan Biologi. Bogor. 
Ng, T.K. and Kenealy, W.R. 1986. Industrial applications of thermostable enzymes. In: Brock, T.D. (Ed). Thermophiles. General, Molecular and Applied Microbiology. 197-215 pp. Wiley. New York.

Nigam, P. and Singh, D. 1995. Enzyme and microbial systems involved in starch processing. Enzyme. Microb. Technol. 17:770-778.

Nishise, H., Fuji, A., Ueno, M., Vongsuvanlert, V. and Tani, Y. 1988. Production of raw cassava starchdigestive glucoamylase by Rhizopus sp. in liquid culture. J. Ferment. Technol. 66:397-402.
Sen, S. and Chakrabarty, L. 1984. Amylase from Lactobacillus cellobiosus isolated from vegetable wastes. J. Ferment. Technol. 62:407413.

Veltkamp, H.J. and de Bruijn, G.H. 1996. Plant resources of South-East Asia No. 9. In: Flach, M. Rumawas, F. (Eds). Plant Yielding Non-seed Carbohydrates. pp. 55-92. Buchny Pub. Leiden. 